\title{
WHY TRAVEL MOTIVATION AND SOCIO-DEMOGRAPHICS MATTER IN MANAGING A NATIONAL PARK
}

Authors:

Melville Saayman ${ }^{1}$

Andrea Saayman ${ }^{1}$

\section{Affiliations:}

${ }^{1}$ Institute for Tourism,

Wildlife Economics \&

Leisure Studies and

School of Economics,

North-West University,

South Africa

Correspondence to:

Melville Saayman

e-mail:

melville.saayman@nwu. ac.za

\section{Postal address:}

Private Bag X6001,

Potchefstroom, 2520,

South Africa

\section{Keywords:}

conservation and

tourism; sociodemographics; travel

motivation; travel

behaviour; Addo

Elephant National Park

\section{Dates:}

Received: 18 Sep. 2008

Accepted: 07 May 2009

Published: 25 June 2009

How to cite this article: Saayman, M. \& Saayman, A., 2009, Why travel motivation and sociodemographics matter in managing a national park, Koedoe 51(1), Art. \#381, 9 pages. DOI:

10.4102/koedoe.v51i1.381

This article is available at:

http://www.koedoe.co.za

(C) 2009. The Authors. Licensee: OpenJournals Publishing. This work is licensed under the Creative Commons Attribution License.

\section{ABSTRACT}

The Addo Elephant National Park is one of only a few national parks in the world that offers the Big 7 experience and is therefore one of South Africa's prime tourism destinations. The park plays an important role in the regional economy and has become a hub for tourism development. The aim of this article is to determine the extent to which socio-demographic and behavioural and motivational indicators influence the spending of tourists to the park. A better understanding of the latter could help marketers and planners to increase the economic impact of the park. Since 2001, surveys have been conducted among tourists to the park and have included a number of socio-demographic, behavioural and motivational questions. In this analysis, 537 questionnaires were used. The methodology used includes factor analysis, cross-sectional regression analysis and pseudo-panel data analysis to determine and compare possible influences on spending. The research identifies six motives for tourists travelling to the Addo Elephant National Park; these are nature, activities, family and socialisation, escape, attractions and photography. The research found that a combination of socio-demographic and motivational factors influences visitor spending decisions. Added to this, the research confirms that tourist attractions, including national parks, differ from one another and that the variables that influence spending therefore also differ.

Conservation implications: In order for national parks to fulfil their conservation mandate, they require funding. One of the main sources of income for national parks is tourist spending. This article identifies the socio-demographic and motivational factors that influence tourist spending. Hence, park management can use these results in order to market and create opportunities for tourists to spend more thereby benefiting conservation directly.

\section{INTRODUCTION}

Addo Elephant National Park (AENP) was proclaimed in 1931 to protect the 11 remaining Eastern Cape elephants and a few free-roaming buffalo that also remained in the area. In 1954, an elephant-proof fence was constructed to prevent the animals from wandering onto surrounding farmland. The protection programme proved to be successful and the numbers of the animals increased from only 18 in 1954 to well over 100 in 2007. Addo is situated close to Port Elizabeth in the Eastern Cape in South Africa (see Figure 1) and lies in gently undulating country, where $90 \%$ of vegetation consists of spekboom and other woody species (known locally as Addo bush), with Karoo scrub and grassland making up the remainder.

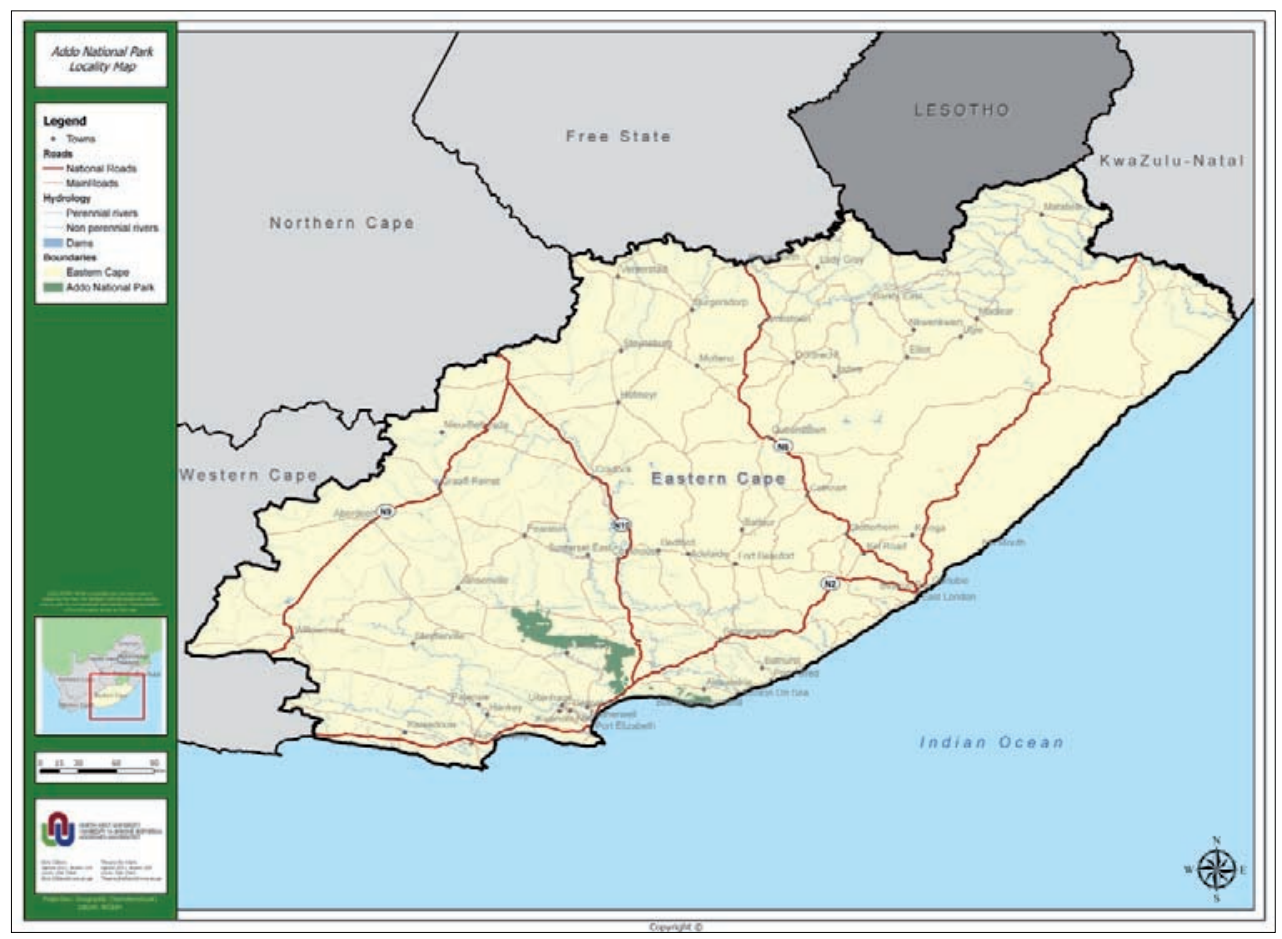

FIGURE 1

Addo Elephant National Park 
Today, the park hosts a variety of game species besides elephants. There are more than 160 bird species and the park is also home to the flightless dung beetle. Plans to expand the 125000 ha (309 000 acre) Addo Elephant National Park to a 492000 ha (1.2 million acre) 'Greater Addo' park are progressing at an exciting pace. The uniqueness of this park lies in the fact that it is one of the few parks in the world that offers the Big 7 (elephant, lion, black rhino, buffalo, leopard, the great white shark and seasonal southern right whale in the marine section complete the Big 7), which implies that the park is also a marine reserve and that it includes a few islands (SANParks 2009).

A socio-economic impact analysis by Saayman and Saayman (2006) on the AENP indicates that the park plays a significant role in employment, production and general income creation in the region and that $35 \%$ of businesses in the region have been established directly as a result of the park. This is due to the growing number of tourists visiting the park and therefore the area and to investments by the private sector. For the AENP to attract the right market as well as to develop the right products and services, it is important that marketers understand the spending behaviour of visitors, for this has direct bearing on the economic impact. South African National Parks (SANParks), which is the conservation authority managing national parks in South Africa, has, as one of its functions, the important role of creating benefits for local communities by means of job creation and of improvement in the quality of life of local inhabitants. According to Van der Merwe, Saayman and Krugell (2006), economic impact is influenced by the length of stay, the number of tourists, the multiplier effect and the amount spent by tourists. Hence, a greater understanding of spending behaviour could assist marketers and product developers, firstly in targeting the right market and, secondly, in developing the right products and services. The purpose of this paper is to determine the extent to which travel motivation and socio-demographic indicators influence the spending of tourists to the AENP.

Lamb, Hair and McDaniel (2002) state that tourists or consumers do not make purchase decisions in isolation. The mix of cultural, social, personal and psychological factors and previous experiences, all of which influence behaviour, is largely uncontrollable. Because of the influence exerted on buying patterns, it is essential that as much effort as possible is put into understanding how these factors interact and, ultimately, how they influence these decisions. From the theory of consumer behaviour, personal factors refer to the socio-demographic characteristics of individuals (gender, age, level of education, family life cycle, social class, place of residence etc.) and to those of a psychological nature (motivations, values, personality, lifestyle etc.). These personal factors affect an individual's cognitive organisation or evaluation of stimuli and therefore also influence the perceptions of the environment and the resulting image (Baker \& Crompton 2000; Beerli, Josefa \& Martin 2003). In the socio-demographic profile, behaviour can be described as the mental, emotional and physical activities in which people engage when selecting, purchasing, using and disposing of a product or service to satisfy needs and desires (Wilkie 1994).

In support of the notion that many factors influence purchase decisions, researchers such as Cai, Hong and Morrison (1995), Walker, Scott-Melnyk and Sherwood (1996), Lu and Pas (1999), Jang et al. (2004), Saayman and Saayman (2006) and Van der Merwe et al. (2006) all support the notion that socio-demographic determinants have an effect on activity, participation and travel behaviour. For example Jang et al. (2004), Fish and Waggle (1996) and Van der Merwe et al. (2006) find that socio-demographic variables can be used to explain travel behaviour and the relationship between variables.

The only other study that identifies the socio-demographic determinants of spending for a national park in South Africa is by Saayman and Saayman (2007). Their results show that a combination of demographic, behavioural and motivational factors influences spending at AENP. Behavioural indicators are the most significant in the case of the Kruger National Park (KNP) and include the number of days spent, the size of a travel group, the frequency of visits and catering preferences. Their research contradicts findings by Downward and Lumsdon (2002) and Skuras, Simara and Petrou (2005), who find that an increase in the size of a travel group leads to increased spending. Oppermann (1996) finds that repeat visitors spend less than firsttime visitors, although Gyte and Phelps (1998) find the opposite, while Jang et al. (2004) conclude that the frequency of visitation is an influencing factor in visitor expenditure. In the case of the KNP, Saayman and Saayman (2007) show similar results to those of Oppermann (1996). Language and the province of origin are found by Saayman and Saayman (2006) to be significant in the case of arts festivals in South Africa.

The role of age on spending is not conclusive. Studies by, for example, Mok and Iverson (2000) and Kastenholz (2005) find a positive relationship between age and spending, while Mumdambi and Baum (1997) indicate an inverse relationship between age and spending. Van der Merwe et al. (2006) and Letho et al. (2004) find that older people tend to spend more.

The reason for or purpose of travel, according to Letho et al. (2004) and Sakai (1988), has a definite impact on expenditure levels. Saayman and Saayman (2006) report that attracting high spenders instead of crowds is desirable not only from an economic-impact point of view but also from an environmental point of view. In the context of an attraction such as the AENP, this is important because conservation areas have to create income but with as little environmental impact as possible.

With regard to motivational factors, Van der Merwe and Saayman (2008) conducted research on the travel motives of visitors to the KNP in South Africa. Similar research includes that by Tao, Eagles and Smith (2004) for the Taroko National Park in Taiwan and by Uysal, McDonald and Martin (1994) for visitors to a national park in the USA. The conclusion of the study by Uysal et al. is that visitor motives in visiting various parks differ. To escape from routine was the only motive that repeated itself. This can therefore be regarded as the most common motive for travelling to a tourist destination. No study, however, could be found that combines a motivational and a socio-demographic analysis in trying to get a better understanding of spending by visitors to national parks.

From the literature review, it is clear that the determinants of spending differ from destination to destination and from product to product. The issue that then arises is that, if this is indeed the case, there would surely be differences among various national parks and, if so, the issue then is what these differences would be, since the only other comparable study done in national parks that can be used as a reference is that of the KNP.

\section{METHOD}

To gather data from visitors to the Addo Elephant National Park, a visitor questionnaire was administered from 2001 to 2007. The method of research is discussed under three headings: (i) the questionnaire, (ii) the samples and (iii) the methods.

\section{Questionnaire}

The visitor questionnaire administered at the park has been used in previous national parks research, including the Kruger National Park, the Tsitsikamma National Park, the Karoo National Park and the Kgalagadi Transfrontier Park. The questionnaires were handed out at the camp-sites and chalets in the early evening by fieldworkers and collected later that evening or early the following morning by the same fieldworkers. Only overnight visitors are therefore included in the survey. The questionnaire remained fairly consistent over the years from 2001 to 2007, with only minor adjustments made over this time. The questionnaire administered in 2001 can be viewed as the 
TABLE 1

Visitor-survey questions used and their descriptions

\begin{tabular}{|c|c|c|}
\hline CATEGORY & QUESTION DESCRIPTION & VARIABLE \\
\hline Socio-demographic & $\begin{array}{l}\text { Home language: English }=1 \text {, Afrikaans }=2 \text {, other }=3 \\
\text { Age: }<19=1,20-24=2,25-34=3,35-49=4,50-64=5,65+=6 \\
\text { Marital status: married }=1, \text { unmarried }=2 \text {, divorced }=3 \text {, widow/er }=4 \text {, living together }=5 \\
\text { Residing province: Gauteng }=2 \text {, Western Cape }=3, \text { Northern Cape }=4 \text {, Mpumalanga }=5 \text {, North West }=6 \text {, KwaZulu-Natal }=7 \text {, } \\
\text { Free State }=8 \text {, Eastern Cape }=9 \text {, Limpopo }=10, \text { non-SA }=1 \\
\text { Highest qualification: no school }=1 \text {, matric }=2 \text {, diploma/degree }=3 \text {, postgrad }=4 \text {, professional }=5 \text {, other }=6\end{array}$ & $\begin{array}{l}\text { LANG. } \\
\text { AGE } \\
\text { MARRY } \\
\text { PROV. } \\
\text { QUAL. }\end{array}$ \\
\hline Behavioural & $\begin{array}{l}\text { Group size (fill in) } \\
\text { Number of visits to national parks over past three years (fill in) } \\
\text { Number of nights (fill in) } \\
\text { Wildcard (only 2006-2007): yes }=1 \text {, no }=2 \\
\text { Preference for catering (only 2004-2007): self-catering }=1 \text {, dine out \& self-catering = 2, B\&B = 3, dinner, bed \& breakfast = } 4\end{array}$ & $\begin{array}{l}\text { PEOPLE } \\
\text { VISITS } \\
\text { DAYS } \\
\text { WILD-CARD } \\
\text { PREF. }\end{array}$ \\
\hline Motivational & $\begin{array}{l}\text { Scale importance of reasons for visiting park from } 1 \text { to } 5 \text { ( } 1=\text { not important; } 5=\text { very important): } \\
\text { To get away from my regular routine } \\
\text { To relax } \\
\text { To explore a new destination } \\
\text { To spend time with friends } \\
\text { For the benefit of my children } \\
\text { For family recreation } \\
\text { To learn about wildlife } \\
\text { To develop appreciation for endangered species } \\
\text { For educational reasons (to increase knowledge) } \\
\text { To learn about animals in general } \\
\text { To learn about endangered species } \\
\text { To learn about plants } \\
\text { To learn about specific animals } \\
\text { To photograph animals } \\
\text { To photograph plants } \\
\text { Because I grew up with the park } \\
\text { It's a well-known brand } \\
\text { The park has great accommodation facilities } \\
\text { I prefer this area because of the climate } \\
\text { To do the hiking trails } \\
\text { For conferences (only since 2003) } \\
\text { For events in the area (only since 2003) }\end{array}$ & $\begin{array}{l}\text { ROUTINE } \\
\text { RELAX } \\
\text { EXPLORE } \\
\text { FRIENDS } \\
\text { CHILD. } \\
\text { FAMILY } \\
\text { WILDLIFE } \\
\text { ENDANG. } \\
\text { EDU. } \\
\text { ANIMALS } \\
\text { SPECIES } \\
\text { PLANTS } \\
\text { SANIM. } \\
\text { PHOTOA. } \\
\text { PHOTOP. } \\
\text { GREWUP } \\
\text { BRAND } \\
\text { ACC. } \\
\text { CLIMATE } \\
\text { HIKING } \\
\text { CONF. } \\
\text { EVENTS }\end{array}$ \\
\hline
\end{tabular}

testing phase of the questionnaire and most of the problems experienced with data analysis from the 2001 questionnaire were corrected in subsequent years. One example of such a problem is that spending data were gathered in spending categories (e.g. R0-R250, R250-R500 etc.) in 2001, which proved to have limited use in the analysis.

The first section of the questionnaire deals with the sociodemographic information of the respondents, including age, marital status and qualification. In the early years of the questionnaire (2001 and 2002), income categories were also included. The response rate on these was very low and this category was subsequently dropped from the questionnaire.

The second section of the questionnaire focuses on spending behaviour during the visit to the park and on motivations for the visit. The amount spent on various items is asked, while motivations for the visit to the park are answered on a 5-point Likert scale (Maree 2007), where $1=$ unimportant and $5=$ very important. The qualitative questions were coded to enable them to be used in the analysis. The questions used and the codes assigned to them are indicated in Table 1.

It should be noted that the province variable was coded to reflect income per capita in the province, with $1=$ highest income per capita and $10=$ lowest income per capita. One would therefore expect the sign of the coefficient to be positive, since people from richer provinces would be expected to spend more. Another variable that may need clarification is that of the Wildcard. In 2005, SANParks introduced a loyalty card known as the 'Wildcard'. This card can be bought from SANParks and gives the holder free entry to all the national parks in South Africa. It thus constitutes a discount on entry and conservation fees. This could therefore either have a negative impact on spending while Wildcard holders are at the park or it could be that visitors decide to spend extra on other items, since they are saving on conservation fees.
The dependent variable is spending per person, which was calculated by adding the spending of the respondents on the various components asked and subtracting transport cost to the park from the number obtained. This gave total spending excluding transport, which was then divided by the number of people whom the respondents were paying for on the trip to give spending per person. The reasons why transport cost is excluded are that spending on transport does not normally take place in the park and that transport from an origin further away would inflate spending per person. The natural logarithm of all variables was taken to standardise the data and ease interpretation.

\section{Sample}

The survey was conducted once yearly from 2001 to 2005 and two surveys have been conducted annually since 2006, which leads to more respondents and could improve conclusions drawn from the survey. The number of questionnaires administered and the months surveyed are indicated in Table 2. This table also indicates the total number of visitors to the park during these years, which includes both overnight and day visitors. To have a better idea of the proportion of visitors who are overnight visitors, the unit nights sold (including camping nights) are also indicated. Again, this is only an approximation, since most visitors stay for more than one night. Overnight travel parties during one year can be derived by dividing the unit nights sold by the average nights spent in the park for that year (according to every year's survey). If this number is equally divided by 12 months, visitor groups per month can be guesstimated.

It can be clearly seen that the response rate for each month of the survey ranges between a low of $4 \%$ to a high of $7.4 \%$. This low response could lead to response bias, which should be noted. The surveys are therefore, however, analysed both in crosssection and as a pseudo-panel. 
TABLE 2

Total number of questionnaires administered to tourists during a marketing survey at Addo Elephant National Park between 2001 and 2007

\begin{tabular}{|c|c|c|c|c|c|c|c|c|c|}
\hline YEAR & 2001 & 2002 & 2003 & 2004 & 2005 & \multicolumn{2}{|c|}{2006} & \multicolumn{2}{|c|}{2007} \\
\hline Survey month & May & July & December & November & November & July & November & June & November \\
\hline \# of questionnaires & 64 & 35 & 59 & 82 & 67 & 91 & 50 & 68 & 91 \\
\hline Total guests & & 122,123 & 117,037 & 132,734 & 140,178 & \multicolumn{2}{|c|}{160,810} & \multicolumn{2}{|c|}{162,884} \\
\hline Unit nights & & 26,426 & 32,021 & 37,364 & 43,458 & \multicolumn{2}{|c|}{45,749} & \multicolumn{2}{|c|}{46,546} \\
\hline Visitor groups & & 8,008 & 13,922 & 13,344 & 12,782 & \multicolumn{2}{|c|}{15,250} & \multicolumn{2}{|c|}{18,041} \\
\hline Groups per month & & 667 & 1,160 & 1,112 & 1,065 & 1,271 & 1,271 & 1,503 & 1,503 \\
\hline
\end{tabular}

Compiled from visitor statistics received from SANParks (2002-2008)

\section{STATISTICAL ANALYSIS}

To reduce the number of motivations and aid in the interpretation of data, a factor analysis was firstly undertaken. One additional advantage of such an analysis is that it reveals relationships that were not previously suspected (Johnson \& Wichern 2002). The purpose of factor analysis is normally to describe the covariance relationships among many variables in terms of a few underlying but unobservable random quantities known as 'factors'. According to Johnson and Wichern (2002), the factor model can be motivated by the following argument: Suppose that all variables in a particular group are highly correlated among themselves and can therefore be grouped according to their correlations. The variables in a group do, however, have small correlations with variables in other groups. This being the case, it is conceivable that each group of variables represents a single underlying factor that is responsible for the observed correlations.

Using the results from the factor analysis, the motivational variables were grouped into the factors (based purely on averages for each factor) and included in the subsequent analyses. To determine the influence of these factors on spending behaviour, regression analysis was undertaken. Regressions were first undertaken for each year, in other words cross-sectional regression analysis was undertaken. The model estimated is as follows:

$y_{i}=\alpha+x_{i} \beta+\varepsilon_{i}$, with $i=1,2,3 \ldots \mathrm{n}$

where $y_{i}=$ spending per person, $x_{i}=$ vector of explanatory variables (as indicated in Table 1 ) and $\varepsilon_{i}=$ i.d.d. error term

Wooldridge (2002) notes that, in a random sampling context, errors are always independent and identically distributed, regardless of how they are related to $x$. To avoid the inclusion of too many variables, a stepwise least squares regression was used. EViews 6 was used in all the estimations. The method used in selecting the variables to be included is the stepwiseforwards, which starts with no additional regressors in the regression and then adds variables based on their p-values. The variable with the lowest $p$-value is chosen and added, and this process continues until there is no variable left with a p-value less than the included variables (QMS 2007). The results of the stepwise regression were then subjected to diagnostic analyses and, where necessary, changes were made to reach the final regression model.

Since the survey was repeated over a number of years, the data obtained can also be viewed as a panel consisting of both a crosssection and a time component. Yet Inoue (2008) notes that repeated cross-sections from survey data cannot be treated as genuine panels and a pseudo-panel should therefore be constructed. Pseudo-panels are constructed by grouping individuals together according to some characteristic and averaging the observations in each group or cohort (Saayman \& Saayman 2007). Since this is done for every cross-section, a time dimension is again obtained (Cottrell \& Gaubert 2003). The pseudo-panel data model that is then estimated is as follows (Inoue 2008):

$\bar{y}_{s t}=\bar{\alpha}_{s t}+\delta_{s}+\theta^{\prime} \bar{w}_{s t}+\bar{\varepsilon}_{s t^{\prime}}$ for $\mathrm{s}=1, \ldots \mathrm{S}, \mathrm{t}=1, \ldots, \mathrm{T}$

where $\mathrm{s}$ indicates the different cohorts and $\mathrm{t}$ indicates time
The bar above the variable denotes that it is an average observation, since cohorts are created via averaging individual observations. $\bar{\alpha}_{s t}$ denotes the intercept and captures the average of the individual specific effects that constitute group $\mathrm{s}, \delta$ captures the group-specific effects and $\bar{w}_{\text {st }}$ captures the grouptime-specific explanatory variables (see Table 1 for variables used in the analysis) and the individual-specific characters included in each group.

A characteristic often employed to create cohorts is age or date of birth (Cottrell \& Gaubert 2003). Thus, for every cross-section, individuals were grouped into the six age groups described in Table 1. Age group 1 had very few observations in all years, however, and age groups 1 and 2 had to be merged, since it is a prerequisite for pseudo-panel data that the number of individuals in each group must be large relative to the number of groups and time periods. To ensure homoskedasticity in random errors, Matas and Raymond (2007) suggest that variables are weighted by the square root of the number of individuals in each cohort. This procedure was followed, which rendered all variables continuous.

The same procedure was followed as with the cross-section analysis, where a stepwise regression indicated the independent variables that should be included before diagnostic tests were completed. Inoue (2008) shows that using fixed effects when estimating the pseudo-panel model accounts for group effects. This is also taken into consideration in the final estimates.

\section{RESULTS}

Since the questionnaire responses were subjected to three types of analyses, the results are described accordingly.

\section{Results of the factor analysis}

The data used in the factor analysis comprised only the motivational factors (as described in Table 1). All missing values were identified and any respondent who did not complete at least two-thirds of the motivational questions was omitted from this analysis. To determine the number of factors that should be used in analysis, the rule of thumb is normally that all factors with eigenvalues greater than unity must be extracted (Johnson \& Wichern 2002). Using SPSS 16.0 for Windows ${ }^{\circledR}$ (SPSS Inc. 2007), six factors were therefore extracted with eigenvalues greater than unity. Together, these six factors explain $64.384 \%$ of the variance. The rotated method was chosen, since it provides a simpler structure and more detailed focus. According to both the Varimax and Promax rotated method, the same structure was found. Table 3 indicates the structure according to the Varimax procedure.

Although the variables do not all load very strongly on the factors, the authors tried to keep as many motivational variables as possible for further analysis. The general rule applied is a loading of more than 0.4 on the factor or a loading of less than 0.4 when it loads almost double on one factor than on any other factor. Using these basic guidelines, only the motivational factor 'explore' does not load clearly onto any factor and it is thus the only motivational factor that is ignored in further analyses. 
TABLE 3

Results of factor analysis conducted on motivational factors

\begin{tabular}{|c|c|c|c|c|c|c|}
\hline & \multicolumn{6}{|c|}{ FACTOR } \\
\hline & 1: NATURE & 2: ACTIVITIES & 3: FAMILY & 4: ESCAPE & 5: ATTRACTIONS & 6: PHOTOGRAPHY \\
\hline MEAN VALUE (OUT OF 5) & 2.88 & 1.74 & 2.98 & 3.83 & 2.81 & 3.11 \\
\hline Routine & 0.049 & -0.045 & 0.047 & 0.686 & 0.125 & 0.031 \\
\hline Relax & -0.068 & -0.012 & 0.168 & 0.867 & 0.105 & 0.008 \\
\hline Explore & 0.150 & -0.022 & 0.137 & 0.184 & 0.108 & 0.053 \\
\hline Friends & 0.030 & 0.188 & 0.353 & 0.084 & 0.086 & 0.045 \\
\hline Children & 0.005 & 0.155 & 0.585 & 0.097 & 0.022 & -0.106 \\
\hline Family & -0.002 & -0.053 & 0.470 & 0.393 & 0.152 & 0.034 \\
\hline Wildlife & 0.162 & -0.006 & 0.900 & -0.002 & 0.101 & 0.061 \\
\hline Species & 0.348 & 0.032 & 0.703 & 0.088 & -0.048 & -0.065 \\
\hline Education & 0.584 & 0.187 & 0.291 & -0.058 & 0.033 & 0.005 \\
\hline Animals & 0.801 & -0.023 & 0.010 & -0.018 & 0.048 & 0.114 \\
\hline Endanger & 0.903 & 0.018 & 0.067 & 0.119 & 0.059 & 0.102 \\
\hline Plants & 0.718 & 0.250 & 0.085 & 0.046 & -0.033 & 0.012 \\
\hline Sanim. & 0.656 & 0.219 & 0.118 & 0.008 & 0.058 & 0.150 \\
\hline Photoa. & 0.300 & 0.054 & -0.020 & 0.110 & 0.079 & 0.942 \\
\hline Photop. & 0.316 & 0.540 & -0.097 & -0.012 & -0.136 & 0.346 \\
\hline Grewup & 0.083 & 0.663 & 0.065 & 0.026 & 0.103 & -0.123 \\
\hline Brand & 0.059 & 0.531 & 0.193 & 0.011 & 0.271 & -0.009 \\
\hline Acc. & -0.009 & 0.118 & 0.173 & 0.256 & 0.864 & 0.010 \\
\hline Climate & 0.174 & 0.261 & 0.031 & 0.272 & 0.424 & 0.068 \\
\hline Hiking & 0.167 & 0.598 & 0.148 & 0.043 & 0.101 & 0.014 \\
\hline Conf. & 0.096 & 0.787 & 0.104 & -0.061 & -0.024 & -0.038 \\
\hline Events & 0.010 & 0.478 & -0.030 & -0.076 & 0.001 & 0.128 \\
\hline
\end{tabular}

For a full description of the statements, see Table 1

Given the content of these factors, the motivations for visiting the AENP can be described as follows:

\section{- Factor 1: Nature}

This motive includes aspects such as educational reasons, endangered species and seeing animals and plants. It has the fourth highest mean value (2.88). The motive is confirmed by researchers such as Van der Merwe and Saayman (2008), Oh, Uysal and Weaver (1995) and Swanson and Horridge (2006) as a motive for travel. Similar research by Van der Merwe and Saayman (2008) completed for the KNP in South Africa identifies this factor as a primary motive for visiting national parks in South Africa.

\section{- Factor 2: Activities}

'Activities' includes the photography of plants, hiking, conferences and events. This motive has also been found as a reason why visitors travel to the KNP in South Africa (Van der Merwe \& Saayman 2008). Oh et al. (1995) have also found activities to be an important travel motivation in their research, although, in this case, it has the lowest mean value of all the motives (1.74).

- Factor 3: Family and socialisation

This motive includes being with one's family and friends, and experiencing wildlife and different species with family members - hence the aspect of socialisation. Research on national parks in the USA conducted by Uysal et al. (1994) identifies a similar motive, namely the enhancement of kinship relations. Yet this aspect has not been found to be a priority in KNP research. At the KNP, the motive of nostalgia is strong, which confirms many other studies in the field (Backman et al. 1995; Lee, Lee \& Wicks 2004; Schneider \& Backman 1996). Possible reasons for this could be because it is not only a well-known and established park but also the oldest national park in South Africa. This is not the case for the AENP. The motive has a mean value of 2.98, which indicates high relative importance.

\section{- Factor 4: Escape}

This motive consists of two aspects, namely to relax and to break away from routine. This motive is confirmed by a great number of researchers, such as Kim, Borges and Chon (2006), Uysal et al. (1994), Swanson and Horridge (2006) and Van der Merwe and Saayman (2008). It also has the highest mean value, indicating that it is the most important motive for tourists visiting the AENP.

\section{- Factor 5: Attractions}

Attractions include accommodation and climate, and this motive has a mean value of 2.81. Kim et al. (2006) and Van der Merwe and Saayman (2008) also find attractions to be a motive for visiting national parks, although Bansal and Eislet (2004) find climate to be a separate motive for the visiting of destinations.

- Factor 6: Photography

This motive entails the photography of animals; no other research identifies a similar motive. This aspect can therefore be regarded as a unique motive for travel to the AENP. It is also rated second highest, with a mean value of 3.11.

\section{Results of the cross-sectional analyses}

Based on the motivational factors identified above, the average for each factor was determined for each respondent. These factors (motives 1 to 6 described above) were then included in the regression models. For the purpose of the regression models, only respondents who sufficiently answered the spending section 
TABLE 4

Variables identified with stepwise regression from 2002 to 2007

\begin{tabular}{llllll}
\hline $\mathbf{2 0 0 2}$ & $\mathbf{2 0 0 3}$ & $\mathbf{2 0 0 4}$ & $\mathbf{2 0 0 5}$ & $\mathbf{2 0 0 6}$ & $\mathbf{2 0 0 7}$ \\
\hline Motive 6 & Motive 6 & Motive 4 & Prov. & Prov. & Days \\
People & Visits & Visits & Qual. & Days & Pref. \\
Motive 1 & People & Qual. & Motive 6 & Motive 5 & Prov. \\
Marry & Prov. & Lang. & Lang. & Motive 6 & Wildcard \\
Age & Pref. & Motive 2 & Motive 2 & Motive 1 & Qual. \\
Qual. & Days & Prov. & Motive 3 & Qual. & Lang. \\
Motive 5 & Motive 1 & & Motive 1 & Marry & Motive 1 \\
Motive 2 & Age & & Motive 4 & Wildcard & Motive 4 \\
Prov. & Motive 5 & & People & Visits & \\
& & & Marry & Pref. & \\
\hline For a full
\end{tabular}

(thus, have spending data) and data for people for whom she or he was paying could be used in the analysis, since spending per person is the dependent variable. In addition, 2001 spending data were categorised and could not be used, and the crosssection and pseudo-panel analyses were therefore conducted on the data from 2002 to 2007 only. This led to an adjusted sample for each year: (i) 2002, 28 respondents; (ii) 2003, 48 respondents; (iii) 2004, 66 respondents; (iv) 2005, 43 respondents; (v) 2006, 123 respondents; (vi) 2007, 128 respondents.

The variables identified for each year by the stepwise regression are indicated in Table 4. It is clear from Table 4 that both sociodemographic and motivational factors play a role in the spending patterns of visitors to the AENP.

These variables were used to determine the final model for each year. In the final models, adjustments to account for heteroskedasticity were made and the models were tested for over-specification. The final cross-sectional models are indicated in Table 5.

\section{From Table 5, the following is evident:}

- A combination of socio-demographic and motivational factors influences visitor spending decisions. This research therefore confirms similar findings by Cai et al. (1995), Walker et al. (1996) and Lu and Pas (1999).

- The weak proxies for income, namely qualification and province of origin, appear in all the cross-section regressions. Yet they are not significant everywhere. Where significant, they show the expected sign (positive), except for 2007, where province of origin has a negative sign. A reason for this may be that most respondents are from the Eastern Cape Province and that, even though it is a relatively poor province, close vicinity to the park may have a positive impact on spending.

- Although age appears in some of the regressions, nowhere is it a significant determinant of spending, which again supports the notion that the role of age is not conclusive.

- The marital status of respondents is significant only in 2002 The negative coefficient indicates that single people tend to spend more per person than married couples. This research supports findings by Saayman and Saayman (2007) for the KNP. A possible reason for this is cost sharing by couples.

- Although language appears as an explanatory variable in three years, it is significant only in 2004. An interesting result is that the sign is negative, indicating that Englishspeaking people spend more than Afrikaans-speaking and overseas visitors. This contradicts previous research completed in South Africa on arts festivals (Saayman \& Saayman 2006)

- As expected, the larger the number of tourists who travel together, the lower the spending per person, since costs are shared. Tourists with more elaborate catering needs tend to spend more, which is to be expected. The same applies to tourists who stay longer. In this regard, this research confirms findings by Saayman and Saayman (2007).

- An interesting finding is that repeat visitors tend to spend less, although this is true only for two of the years and the finding is significant only for 2003. This finding supports Opperman (1996), who also finds that repeat visitors tend to spend less than first-time visitors, but contradicts findings by Gyte and Phelps (1998) and Jang et al. (2004).

- While all regressions include motivational factors that were identified via the stepwise regressions as having an influence on spending, only the motives of nature, photography, escape and attractions are significant. These are also motives with a high mean value. Park management should take note of this.

\section{Results of the pseudo-panel analysis}

To construct the pseudo-panel, the data were divided into age cohorts. Since limited data were available, especially for the early years, only four age cohorts were formed for each year. These were (1) under 24 years, (2) 25 to 34 years, (3) 35 to 49 years and (4) older than 50 years. The data in each cohort represent the average for the group, which was weighted with the square root of the number of observations. Finally, the natural logarithm of the variables was taken to standardise the data.

The analysis process followed was similar to that of the crosssection analysis. The results of the stepwise regression indicate that all the motivational factors are identified as factors that explain the variance in spending magnitudes. A number of behavioural variables is also important. These variables are the number of people travelling together, the number of times that the respondents visit national parks and the number of nights spent at the park. Socio-demographic variables that influenced spending over the years from 2002 to 2007 include the marital status of the respondents, their language and their province of origin.

The model was also subjected to various diagnostic tests, including the Breusch-Pagan-Godfrey heteroskedasticity test and normality tests, before the final model was estimated (Asteriou \& Hall 2007, Gujarati 2003). In the final model, fixed effects are used to account for differences across various cross sections. The results of the final model are indicated in Table 6 .

From Table 6, the following can be concluded:

- More people travelling together in a group are associated with lower spending levels per person, since costs are shared.

- Single people tend to spend more than married people Again, this may be due to married couples sharing costs.

- More frequent visitors to the park tend to spend more while at the park. Repeat visitation thus has a positive effect.

- Higher spending is associated with people who travel to the park to relax and get away from the normal routine (escape motive - [4]).

- Motive 6 (the photography of animals) shows a negative relationship with spending, which may indicate that tourists who focus on photographing animals tend to spend more time driving and searching for the perfect photo rather than spending money at the restaurant or on souvenirs.

\section{MANAGEMENT IMPLICATIONS}

Based on the question of why motivation and socio-demographics matter in managing a national park, the following management implications can be identified from this research:

Firstly, marketers need to analyse both socio-demographic and motivational influences on spending, since a combination of the former impacts on spending. In the case of national parks, this is imperative because national parks have a socio-economic mandate to fulfil concerning the communities bordering the parks. Marketing decisions should therefore be influenced by knowledge of not only the profile of visitors but also the reasons that they visit the parks. To be able to make informed decisions, quality research is a requirement. This implies more than just a normal visitor-opinion survey. 
TABLE 5

Results of the cross-section estimations (Dependent: log of spending per person)

\begin{tabular}{|c|c|c|c|c|c|c|c|c|c|c|c|}
\hline \multicolumn{2}{|c|}{2002} & \multicolumn{2}{|c|}{2003} & \multicolumn{2}{|c|}{2004} & \multicolumn{2}{|c|}{2005} & \multicolumn{2}{|c|}{2006} & \multicolumn{2}{|c|}{2007} \\
\hline VARIABLE & $\begin{array}{l}\text { COEFF \& } \\
\text { PROB }\end{array}$ & VARIABLE & $\begin{array}{l}\text { COEFF \& } \\
\text { PROB }\end{array}$ & VARIABLE & $\begin{array}{l}\text { COEFF \& } \\
\text { PROB }\end{array}$ & VARIABLE & $\begin{array}{l}\text { COEFF \& } \\
\text { PROB }\end{array}$ & VARIABLE & $\begin{array}{l}\text { COEFF \& } \\
\text { PROB }\end{array}$ & VARIABLE & $\begin{array}{l}\text { COEFF \& } \\
\text { PROB }\end{array}$ \\
\hline Constant & $\begin{array}{l}6.912 \\
(0.007)^{\star \star \star}\end{array}$ & Constant & $\begin{array}{l}3.876 \\
(0.001)^{\star \star \star}\end{array}$ & Constant & $\begin{array}{l}7.760 \\
(<0.001)^{\star \star \star}\end{array}$ & Constant & $\begin{array}{l}5.479 \\
(0.000)^{\star \star \star}\end{array}$ & Constant & $\begin{array}{l}5.944 \\
(<0.001)^{\star \star \star}\end{array}$ & Constant & $\begin{array}{l}6.369 \\
(<0.001)^{\star \star \star}\end{array}$ \\
\hline Motive 6 & $\begin{array}{l}-0.615 \\
(0.091)^{*}\end{array}$ & Visits & $\begin{array}{l}-0.979 \\
(0.012)^{\star \star \star}\end{array}$ & Motive 4 & $\begin{array}{l}-0.826 \\
(0.044)^{\star \star}\end{array}$ & Prov & $\begin{array}{l}0.260 \\
(0.081)^{\star}\end{array}$ & Prov & $\begin{array}{l}-0.170 \\
(0.219)\end{array}$ & Days & $\begin{array}{l}0.863 \\
(<0.001)^{\star * \star}\end{array}$ \\
\hline Motive 1 & $\begin{array}{l}1.207 \\
(0.033)^{\star \star}\end{array}$ & Motive 6 & $\begin{array}{l}1.311 \\
(0.009)^{\star * *}\end{array}$ & Qual & $\begin{array}{l}-0.136 \\
(0.755)\end{array}$ & Qual & $\begin{array}{l}1.239 \\
(0.068)^{\star}\end{array}$ & Days & $\begin{array}{l}0.414 \\
(0.017)^{\star * \star}\end{array}$ & Pref & $\begin{array}{l}0.368 \\
(0.025)^{\star *}\end{array}$ \\
\hline People & $\begin{array}{l}-1.126 \\
(0.051)^{\star \star}\end{array}$ & Pref & $\begin{array}{l}1.116 \\
(0.011)^{\star \star}\end{array}$ & Lang & $\begin{array}{l}-0.457 \\
(0.096)^{\star}\end{array}$ & Motive 6 & $\begin{array}{l}-0.534 \\
(0.063)^{\star}\end{array}$ & Motive 5 & $\begin{array}{l}-0.277 \\
(0.306)\end{array}$ & Prov & $\begin{array}{l}-0.194 \\
(0.033)^{\star \star}\end{array}$ \\
\hline Marry & $\begin{array}{l}-1.294 \\
(0.008)^{\star \star \star}\end{array}$ & People & $\begin{array}{l}-1.210 \\
(0.008)^{\star \star *}\end{array}$ & Visits & $\begin{array}{l}-0.219 \\
(0.179)\end{array}$ & Lang & $\begin{array}{l}-0.162 \\
(0.676)\end{array}$ & Motive 6 & $\begin{array}{l}-0.091 \\
(0.612)\end{array}$ & Wildcard & $\begin{array}{l}-0.151 \\
(0.476)\end{array}$ \\
\hline Age & $\begin{array}{l}-1.773 \\
(0.209)\end{array}$ & Prov & $\begin{array}{l}0.738 \\
(0.005)^{\star \star \star}\end{array}$ & & & Motive 2 & $\begin{array}{l}-.214 \\
(0.631)\end{array}$ & Motive 1 & $\begin{array}{l}-0.138 \\
(0.636)\end{array}$ & Qual & $\begin{array}{l}0.123 \\
(0.507)\end{array}$ \\
\hline Qual & $\begin{array}{l}1.199 \\
(0.052)^{\star *}\end{array}$ & Days & $\begin{array}{l}-0.717 \\
(0.0179)\end{array}$ & & & Motive 3 & $\begin{array}{l}-0.651 \\
(0.175)\end{array}$ & Qual & $\begin{array}{l}0.444 \\
(0.129)\end{array}$ & Lang & $\begin{array}{l}-0.201 \\
(0.236)\end{array}$ \\
\hline Motive 2 & $\begin{array}{l}0.647 \\
(0.239)\end{array}$ & Motive 1 & $\begin{array}{l}0.576 \\
(0.207)\end{array}$ & & & Motive 1 & $\begin{array}{l}0.460 \\
(0.208)\end{array}$ & & & Motive 1 & $\begin{array}{l}-0.119 \\
(0.497)\end{array}$ \\
\hline Motive 5 & $\begin{array}{l}-0.754 \\
(0.092)^{\star}\end{array}$ & Age & $\begin{array}{l}0.543 \\
(0.140)\end{array}$ & & & & & & & Motive 4 & $\begin{array}{l}-0.222 \\
(0.354)\end{array}$ \\
\hline Prov & $\begin{array}{l}0.222 \\
(0.429)\end{array}$ & Motive 5 & $\begin{array}{l}-0.507 \\
(0.372)\end{array}$ & & & & & & & & \\
\hline R-squared & 0.632 & R-squared & 0.515 & R-squared & 0.119 & R-squared & 0.222 & R-squared & 0.113 & R-squared & 0.316 \\
\hline $\begin{array}{l}\text { Adj } \\
\text { R-squared }\end{array}$ & 0.412 & $\begin{array}{l}\text { Adj } \\
\text { R-squared }\end{array}$ & 0.387 & $\begin{array}{l}\text { Adj } \\
\text { R-squared }\end{array}$ & 0.037 & $\begin{array}{l}\text { Adj } \\
\text { R-squared }\end{array}$ & 0.013 & $\begin{array}{l}\text { Adj } \\
\text { R-squared }\end{array}$ & 0.062 & $\begin{array}{l}\text { Adj } \\
\text { R-squared }\end{array}$ & 0.262 \\
\hline F-stat & 2.872 & F-stat & 4.018 & F-stat & 1.454 & F-stat & 1.062 & F-stat & 2.231 & F-stat & 5.840 \\
\hline AIK & 2.164 & AlK & 3.149 & AlK & 2.666 & AlK & 2.998 & AlK & 2.834 & AlK & 2.183 \\
\hline SC & 2.651 & SC & 3.555 & SC & 2.861 & SC & 3.357 & SC & 3.004 & SC & 2.404 \\
\hline
\end{tabular}

For a full description of the variables used, see Tables 1 and 3

Secondly, parks have to create an environment where people can spend money. According to the results of this research, the motive of 'activities', which entails aspects such as hiking, conferences and events, has the lowest mean average. It is therefore an aspect where management can do more in terms of product development and promotions to enhance spending on these items and to improve performance as a motive for visits to the park. Photography of animals was identified as the second most-important motive and is also an aspect that has a significant negative impact on current spending. Management therefore needs to create workshops on animal photography and promote opportunities such as a photo shop, events and competitions to reap positive benefits from this important motive.

Thirdly, marketing for the AENP should focus on the motive of escape, since not only does it have the highest mean value but the results also indicate that tourists visiting the park for this motive are high spenders. Current marketing efforts focus strongly on the nature motive, specifically elephants and the Big 7, while the research indicates that this is only the fourth most-important motive. Focusing on the escape motive should be easy to achieve in the setting of national parks and could lead to an increase in high-spending visitors. Escape as a motive has been ignored by marketers in national parks, regardless of the fact that all research, both nationally and internationally, identifies escape as a strong and primary motive for visiting tourist destinations and the purchase of tourist products.

Fourthly, ensuring quality service and products guarantees repeat visits and, coupled to that, the changing needs of tourists have to be taken into account. The pseudo-panel results indicate that, over the six years under investigation, repeat visitors spend more than first-time visitors.

\section{CONCLUSION}

The purpose of this research was to determine the extent to which socio-demographic, behavioural and motivational indicators influence the spending behaviour of tourists to the AENP. The research identifies six motives for tourists travelling to the park. These are nature, activities, family and socialisation, escape, attractions and photography. The research also finds that a combination of socio-demographic and motivational factors influences visitor spending decisions. Added to this, the research confirms that tourist attractions, including national parks, differ from one another and that the variables that influence spending therefore also differ. The final regression models indicate that the main motivational factors that have a significant influence on spending are nature, photography, escape and attractions. An interesting finding is that, although photography is regarded as an important motivational factor, it is negatively related to spending, which has significant management implications.

This research confirms previous research by Saayman and Saayman (2007) and Van der Merwe and Saayman (2008) conducted on the KNP in South Africa by identifying similar motives that influence spending. The motive of escape is also found to be significant for research completed in other parts of the world (e.g. the USA and Taiwan). Photography as a motive, however, could not be found in any other research. Contrary to research by Mok and Iverson (2000), Kastenholz (2005) and Letho et al. (2004), age was not found to have a significant influence on spending during visits to the AENP. The finding by Saayman and Saayman (2007) that more tourists in a travel party leads to lower spending per person at the KNP is confirmed for the AENP.

Greater support for the notion that repeat visitors tend to spend more is also found in the pseudo-panel analysis, thereby supporting previous research by Gyte and Phelps (1998) and Jang et al. (2004). And, while the results for language are not always significant, the coefficient always seems to be negative, indicating that English-speaking tourists tend to spend more at the AENP. This is the opposite to what is found for spending at arts festivals in South Africa (Saayman \& Saayman 2006), where Afrikaans-speaking visitors tend to spend more.

This article contributes to current literature concerning motivational factors that influence the visiting of tourist attractions and events. This is the first time that factor analysis 
TABLE 6

Pseudo panel results

\begin{tabular}{lrrrr}
\hline VARIABLE & COEFFICIENT & STD. ERROR & T-STATISTIC & PROB. \\
\hline C & 4.862458 & 0.618292 & 7.864344 & $0.0002^{* * *}$ \\
MOTIVE 2 & 1.186568 & 0.616428 & 1.924909 & 0.1026 \\
PEOPLE & -1.621337 & 0.413536 & -3.920672 & $0.0078^{* * *}$ \\
MOTIVE 3 & -0.145531 & 1.246690 & -0.116734 & 0.9109 \\
MARRY & 1.401964 & 0.487521 & 2.875698 & $0.0282^{* *}$ \\
MOTIVE 5 & 1.468112 & 0.906699 & 1.619183 & 0.1565 \\
MOTIVE 1 & -0.555628 & 1.129816 & -0.491786 & 0.6403 \\
MOTIVE 6 & -2.273708 & 0.734315 & -3.096364 & $0.0212^{* *}$ \\
VISITS & 0.789413 & 0.266143 & 2.966128 & $0.0251^{* *}$ \\
MOTIVE 4 & 2.294685 & 1.132977 & 2.025359 & $0.0892^{*}$ \\
LANG. & -1.413100 & 0.802130 & -1.761685 & 0.1286 \\
PROV. & 0.047514 & 0.352555 & 0.134770 & 0.8972 \\
DAYS & 0.109996 & 0.272923 & 0.403029 & 0.7009 \\
& & & & \\
\hline
\end{tabular}

EFFECTS SPECIFICATION

\begin{tabular}{|c|c|c|c|}
\hline \\
\hline \multicolumn{4}{|c|}{ Cross-section fixed (dummy variables) } \\
\hline Cross-section 1 & & & -0.1783 \\
\hline Cross-section 2 & & & 0.2556 \\
\hline Cross-section 3 & & & 0.0386 \\
\hline Cross-section 4 & & & -0.1753 \\
\hline R-squared & 0.972223 & Mean dependent var & 7.690098 \\
\hline Adj. R-squared & 0.902780 & S.D. dependent var & 0.697375 \\
\hline S.E. of regression & 0.217443 & Akaike info criterion & -0.058500 \\
\hline Sum squared resid & 0.283688 & Schwarz criterion & 0.734985 \\
\hline Log likelihood & 16.64350 & F-statistic & 14.00029 \\
\hline Durbin-Watson stat & 1.644189 & Prob(F-statistic) & 0.001888 \\
\hline
\end{tabular}

Dependent Variable; sPENDPPMethod; Pane 4

has been used together with regression analysis to determine the influence of different motivational factors on visitor spending. In doing this, sensible management conclusions have been reached. An important methodological aspect of the article that should be highlighted is that cross-section regression results tend to vary significantly for the different years. Some results also show very low levels of reliability in terms of R-square and adjusted $\mathrm{R}$-square. The results from the pseudo-panel are more reliable in these terms. One should therefore guard against the reaching of conclusions on one-off surveys and more effort should be taken to repeat surveys over a number of years to test the reliability of results.

\section{REFERENCES}

Asteriou, D. \& Hall, S.G., 2007, Applied econometrics: A modern approach, rev. edn., Palgrave, New York.

Backman, K.F., Backman, S.J., Uysal, M. \& Sunshine, K.M., 1995, 'Event tourism: An examination of motivations and activities', Festival Management and Event Tourism 3(1), 15-24.

Baker, D.A. \& Crompton, J.L., 2000, 'Quality, satisfaction and behavioural intentions', Annals of Tourism Research 27(3), 785-804.

Bansal, H. \& Eislet, H.A., 2004, 'Exploratory research of tourist motivations and planning', Tourism Management 25, 387396.

Beerli, A., Josefa, J.D. \& Martin, D., 2003, Tourists' characteristics and the perceived image of tourist destinations: A quantitative analysis - a case study of Lanzarote, Spain, University of Las Palmas de Gran Canaria, Gran Canaria.

Cai, L.A., Hong, G. \& Morrison, A.M., 1995, 'Household expenditure patterns for tourism products and services', Journal of Travel and Tourism Marketing 4(4), 15-40.

Cottrell, M. \& Gaubert, P., 2003, Efficient estimators: The use of neural networks to construct pseudo panels, proceedings of the conference WSOM 2003, Kitakiushu, Japan, 11-14 September, n.p.

Downward, P.M. \& Lumsdon, L., 2002, 'Beyond the demand for day-visits', Tourism Economics 9(1), 67-76.
Fish, M. \& Waggle, D., 1996, 'Current income versus total expenditure measures in regression models of vacation and pleasure travel', Journal of Travel Research 35(2), 70-74.

Gujarati, D.N., 2003, Basic econometrics, 4th edn., McGraw-Hill, New York.

Gyte, D. \& Phelps, A., 1998, 'Patterns of destination repeat business: British tourists in Mallorca, Spain', Journal of Travel Research 28(1), 24-28.

Inoue, A., 2008, 'Efficient estimation and inference in linear pseudo-panel data models', Journal of Econometrics 142, 449466.

Jang, S., Bai, B., Hong, G.S. \& O’Leary, J.T., 2004, 'Understanding travel expenditure patterns: A study of Japanese pleasure travellers to the United States by income level', Tourism Management 25, 331-341.

Johnson, R.A. \& Wichern, D.W., 2002, Applied multivariate statistical analysis, 5th edn., Prentice Hall, Upper Saddle River.

Kastenholz, E., 2005, 'Analysis of determinants of visitor spending for the rural tourist market in North Portugal', Tourism Economics 11(4), 555-569.

Kim, H., Borges, M.C. \& Chon, J., 2006, 'Impacts of environmental values on tourism motivations: The case of FICA, Brazil', Tourism Management 27, 957-967.

Lamb, C.W., Hair, J.F. \& McDaniel, C., 2002, Marketing, 6th edn., Thompson Learning, Connecticut.

Lee, C.K., Lee, Y.K. \& Wicks, B.E., 2004, 'Segmentation of festival motivation by nationality and satisfaction', Tourism Management 25, 61-70.

Letho, X.Y., Cai, L.A., O’Leary, J.T. \& Huan, T.C., 2004, 'Tourism shopping preferences and expenditure behaviours: The case of the Taiwanese outbound market', Journal of Vacation Marketing 10(4), 320-332.

Lu, X. \& Pas, E.I., 1999, 'Socio-demographics, activity participation and travel behavior', Transportation Research Part A 33, 1-18.

Maree, K, 2007, First steps in research, Van Schaik Publishers, Pretoria.

Matas, A. \& Raymond, J-L., 2007, Cross-section data, disequilibrium situations and estimated coefficients: Evidence from car ownership demand, Document de Treball, XREAP2007-04: Xarxa de Referéncia en Economia Aplicada.

Mok, C. \& Iverson, T.J., 2000, 'Expenditure-based segmentation: Taiwanese tourists to Gaum', Tourism Management 21(3), 299-305.

Mumdambi, R. \& Baum, T., 1997, 'Strategic segmentation: An empirical analysis of tourist expenditures in Turkey', Journal of Travel Research 36(1), 29-34.

Oh, H.C., Uysal, M. \& Weaver, P.A., 1995, 'Product bundles and market segmentation based on travel motivations: A canonical correlation approach', Hospitality Management 14(2), 123-137.

Oppermann, M., 1996, 'Visitation of tourism attractions and tourist expenditure patterns: Repeat versus first-time visitors', Asia Pacific Journal of Tourism Research 1(1), 61-68.

QMS (Quantitative Micro Software), 2007, EViews6 User Guide II, QMS, Irvine.

Saayman, A. \& Saayman, M., 2006, 'The socio-demographics and visitation patterns of arts festivals in South Africa', Events Management 9(4), 211-222.

Saayman, M. \& Saayman, A., 2007, 'Socio-demographic and behavioural determinants of visitor spending at the Kruger National Park in South Africa', paper presented at the first International Association for Tourism Economics (IATE) conference, Palma de Mallorca, Spain, 26-29 October.

Sakai, M.Y., 1988, A micro-analysis of business travel demand, Applied Economics 20(11), 1481-1495.

SANParks, 2009, 'Greater Addo conservation project', viewed 18 May 2009, from http://www.sanparks.org/parks/addo/ library/documents.php.

Schneider, I.E. \& Backman, S.J., 1996, 'Cross-cultural equivalence of festival motivations: A study in Jordan', Festival Management and Event Tourism 4(3/4), 139-144. 
Skuras, D., Simara, E. \& Petrou, A., 2005, 'Rural tourism and visitor expenditure for local food products', Regional Studies 40(7), 767-779.

SPSS Inc., 2007, SPSS 16.0 for Windows ${ }^{\circledR}$, SPSS Inc, Chicago.

Swanson, K.K. \& Horridge, P.E., 2006, 'Travel motivations as souvenir purchase indicators', Tourism Management 27, 671683.

Tao, C.H., Eagles, P.F.J. \& Smith, S.L.J., 2004, 'Profiling Taiwanese ecotourists using a self-definition approach', Journal of Sustainable Tourism 12(2), 149-168.

Van der Merwe, P. \& Saayman, M., 2008, 'Travel motivations of tourists visiting Kruger National Park', Koedoe 50(1), 154159.
Van der Merwe, P., Saayman, M. \& Krugell, W.F., 2006, The determinants of the spending of biltong hunters, paper presented at the second Australian Wildlife Tourism Conference in Western Australia, Fremantle, Australia, 13-15 August.

Walker, C., Scott-Melnyk, S. \& Sherwood, K., 1996, Reggae to Rachmaninoff: How and why people participate in arts and culture, Urban Institute, Washington DC.

Wilkie, W.L., 1994, Consumer behavior, 3rd edn., Wiley, New York.

Wooldridge, J.M., 2002, Econometric analysis of cross-section and panel data, MIT Press, Cambridge MA.

Uysal, M., McDonald, C.D. \& Martin, B.S., 1994, 'Australian visitors to US national parks and natural areas', International Journal of Contemporary Hospitality Management 6(3), 18-24. 